\title{
ВИХОВНИЙ ВПЛИВ ІНФОРМАЦІЙНИХ ТЕХНОЛОГІЙ НА ОСОБИСТІСНИЙ РОЗВИТОК УЧНІВ
}

Коваль М. М. Виховний вплив інформаційних технологій на особистісний розвиток учнів.

У статті розкривається проблема підготовки підростаючого покоління до повноцінної, плідної життєдіяльності, в умовах розвитку школи нового рівня 3 використанням інформаційних технологій у навчально-виховному процесі як засіб збереження неповторності й унікальності кожної дитини, готової до саморозкриття, запровадження нових інформаційних технологій в освітню галузь, у систему виховання особистості в сучасному світі при повному доступі до інформатизації.

Ключові слова: інформаційно-комунікаційні технології, професійна підготовка, професійні навички, інформаційні технології, мультимедійні засоби, електронні посібники.

Коваль М. Н. Воспитательное влияние информационных технологий на личностное развитие учеников.

В статье раскрывается проблема подготовки подрастающего поколения к полноценной, плодотворной жизнедеятельности, в условиях развития школы нового уровня с использованием информационных технологий в учебно-воспитательном процессе как средства сохранения неповторимости и уникальности каждого ребенка, готового к самораскрытию, внедрения новых информационных технологий в область образования, в систему воспитания личности в современном мире при полном доступе к информатизации.

Ключевые слова: информационно-коммуникационные технологии, профессиональная подготовка, профессиональные навыки, информационные технологии, мультимедийные средства, электронные пособия.

Koval M. M The educational impact of information technology on personal development of pupils.

The article highlights the problem of preparing the younger generation to a full, productive life in the development of new level school using new information technologies and their use in the educational process as a means to preserve the originality and uniqueness of every child ready for self-disclosure. The introduction of new information technologies in the educational sector, education of the individual in the modern world of developing society with full access to information from unrestricted age characteristics is analysed.

Key words: information and communication technologies, training, skills, information technology, multimedia, electronic books.

У другій половині 20 століття людство вступило в новий етап свого розвитку. Українське суспільство на цьому етапі переживає перехід від індустріалізації до інформатизації. У такому суспільстві відкриваються безпрецедентні можливості для розвитку кожної людини. Нині інформаційні технології стали невід'ємною частиною сучасного світу. Складником концепції інформатизації суспільства $є$ сфера вищої освіти. Особливої актуалізації ця проблема набуває стосовно системи виховання, що готує спеціалістів для майбутнього інформаційного суспільства, яке перебуває у 
постійних змінах та розвитку. Інформатизація виховання $є$ процесом забезпечення освітньої сфери, методологією, практикою розроблення та використання сучасних нових інформаційних технологій орієнтованих на реалізацію психолого-педагогічних цілей навчання та виховання. Отже, у розв'язанні проблеми інформатизації важливу роль відведено інформаційним технологіям, одним із ключових елементів яких $\epsilon$ поняття «інформація». Головною метою сучасної освіти є підготовка підростаючого покоління до повноцінної плідної життєдіяльності в умовах розвитку школи нового рівня з використанням інформаційних технологій.

Входження України до Болонської конвенції європейської інтеграції освіти до трансконтинентальної системи комп'ютерної інформації за допомогою мережі Інтернет можливе лише за умов створення національного науково-педагогічного інформаційного простору, запровадження нових інтелектуальних інформаційних форм виховання. Процес інформатизації виховання ініціює:

- удосконалення механізмів управління системою освіти на основі використання автоматизованих банків даних науково-педагогічної інформації, інформаційнометодичних матеріалів та комунікаційних мереж;

- удосконалення методології та стратегії відбору змісту, методів та організаційних форм виховання, що відповідають завданню розвитку особистості учня в сучасних умовах інформаційного суспільства;

- створення методичних систем виховання, орієнтованих на розвиток у зборі, обробленні, передаванні, зберіганні інформаційного ресурсу і продукуванні інформації;

- створення та використання психолого-педагогічних, тестувальних, діагностувальних методик контролю процесу формування. Авторська ідея полягає в умовному поділі інформаційної культури на II блоки самореалізації.

Відповідно, на основі здійсненого аналізу та власного практичного досвіду класного керівника можна виокремити компоненти поняття інформаційної культури:

- інформаційна грамотність;

- інформаційна компетентність;

- інформаційна рефлексія;

- інформаційна культуро творчість.

Види інформації для виховання інформаційної культури учнів: числова, текстова, графічна, звукова, складна.

Нині класний керівник $є$ не лише транслятором культури, а і їі творцем. У цьому плані творчість не має меж: від пошуку нестандартних рішень до створення власних теорій та відкриттів про розроблені психологічні теорії у комп'ютерному вихованні, знання про позитивні та негативні впливи процесів інформатизації та комп'ютеризації, про те як впливає інформатизація на прийоми та способи виховання. Опанування учнями методології комп'ютерного моделювання $є$ ефективним засобом розвитку продуктивного мислення, який сприяє підвищенню мотивації учня $\mathrm{s}$ формуванню стійкого інтересу до пошуково-дослідницької діяльності. Найбільш природнім середовищем моделювання для початкового рівня роботи 3 інформаційними засобами є робота з електронними таблицями.

Враження, які учень отримує у процесі виховання, залишають певний слід, зберігаються і пізніше відтворюються. Адже виховуючи в дитині вміння 3 користю використовувати інформаційні технології, потрібно з урахуванням рекомендацій щодо психологічної готовності учня до роботи з комп'ютером. Мотив змагання, бажання «перемогти», віртуально досягти неосяжного - $є$ важливими стимулами у 
спілкуванні з комп'ютером. Психологічні дослідження розв'язання завдань в умовах діалогу з комп'ютером показали, що в учня виникає мотив змагання, який зокрема виявляється під час тривалої відмови машини працювати. Невід’ємною частиною буття стали інформаційно-комунікаційні технології, які широко впроваджуються i навально-виховні процеси освітніх закладів. Тож хочеться переконати зараз вчителя у тому, що можливості використання IT в організації виховного процесу великі.

Інформаційні технології підвищують i стимулюють інтерес завдяки мультимедійним технологіям; активізують розумову діяльність і ефективність виховання тих або інших якостей особистості завдяки інтерактивності; дозволяють моделювати й візуалізувувати процеси, явища, складні для демонстрації в реальності, але необхідні задля створення повноцінного зорового ряду дозволяють індивідуалізувати виховання, надають учням можливість самостійного пошуку матеріалів, опублікованих в мережі Інтернет для підготовки доповідей, рефератів, складання сценаріїв, надають допомогу в пошуках відповідей на проблемні питання, створюють величезне поле для розвитку креативних ідей, формують загальну інформаційну культуру.

Варто зазначити, що йдеться про принципову зміну організаційних форм i методів виховання. Використання можливостей інформаційної системи, наявної у школі, нівелює значення традиційних форм виховання. Спілкування вчителя й учня не підмінюється технічним пристроєм, воно безпосередньо опосередковується різноманітними видами взаємодії, що доповнюються можливостями комп'ютера. Окрім того, оскільки робота $з$ мультимедійними пристроями стає спільною справою всього шкільного колективу, таке спілкування набуває глибокого змісту.

Викладач розвиває уміння учнів захистити проект, учить відстоювати власну позицію, вести предметну суперечку, брати до уваги рекомендації колективу й керівника. Звертаючи увагу на дизайн під час створення слайдів, розвивається естетичний смак.

Застосування IT надає неоціненну допомогу в методологічній і методичній роботі, роботі із психолого-педагогічного діагностування. Проведення бінарних нестандартних уроків. При підготовці й проведенні батьківських зборів застосування комп'ютера дозволяє обробити й наочно надати батькам результати моніторингу рівня вихованості учнів, їхньої зайнятості в гуртках і клубах і т. д.

Але потрібно пам'ятати: гармонійно приєднатися до багатогранної системи загальношкільних започаткувань, потрібно не займати очікувальну позицію, а поступово набуваючи свій особистий досвід від помилок до перемог, застосовувати у позакласній та загальношкільній практиці.

Використання IT у навчальному процесі початкових класів загальноосвітньої школи, має спектр від використання як засобу, що дозволяє вчителю впливати на організацію педагогічної праці, використовуючи у підготовці до проведення уроків та різноманітних заходів, до використання IT у навчанні самими учнями початкових класів, що дозволяє під час опанування роботи з комп'ютером вправлятися у виконанні низки виховуючих завдань початкової школи 3 використанням комп'ютерних програм.

Робота з комп’ютером учнів початкових класів, зважаючи на окреслені аспекти, може бути, на нашу думку, чинником впливу на особистісні якості дітей. Елементи інформаційних технологій є нині суттєвим компонентом навчання, що формує «нову» грамотність, а тому важливо, щоб кожен учень 3 початкових класів володів елементарними навичками роботи 3 інформаційними технологіями - ефективним засобом удосконалення пізнавальної діяльності. Учні безпосередньо набувають таких 
умінь і навичок: виокремлювати загальне в аналізі конкретних задач; конкретизувати загальні положення в заданій ситуації, проводити дедуктивні міркування; переводити текстову задачу на мову інформаційної моделі; правильно застосовувати поняття й означення; здійснювати умовні систематизації.

Процес розвитку пізнавальної сфери молодшого школяра має гетерохромний характер, що виявляється в кількісних і якісних змінах психологічних детермінант неконтрольованого виховання «вуличної» інформатизації учнів. Нині спостерігається тенденція до розвитку інформаційних технологій (комп'ютери, мобільні телефони та портативні пристрої, ігрові технології і навіть роботи). Варто окреслений інформаційний чинник розвитку людства розглядати на рівні економії, щоб убезпечитись від негативних наслідківу царині виховання цілісної особистості дитини.

\section{Література}

1. Гуревич Р. С. Інноваційно-телекомунікаційні технології в навчальному процесі: посібник [для педагогічних працівників і студентів педагогічних вищих начальних закладів] / Р. С. Гуревич, М. Ю. Кадемія. - Вінниця: ДОВ «Вінниця», 2002. - 116 с. 2. Жук Ю. О. Комп'ютерно-орієнтовані засоби навчання у професійній освіті / Ю. О. Жук // Управління якістю професійної освіти: [зб. наук. пр.] / Укр. інж. пед. акад. - Донецьк, 2001. - С. 273-275. 3. Інноваційні педагогічні технології у трудовому навчанні: навч.-метод. посіб. / [В. Г. Гетта, Р. С. Гуревич, О. М. Коберник та ін.; за ред О. М. Коберника, Г. В. Терещука]. - Умань: [СПД Жовтий], 2008. - 212 с. 4. Корольов В. Б. Використання інформаційно-комунікаційних технологій на уроках трудового навчання (із досвіду вчителя трудового навчання Миронівського НВК. [Електронний pecypc] / $\quad$ В. Б. Корольов. - Режим доступу: http://mnvk2.at.ua 5. Кремень В. Інформаційно-комунікаційні технології в освіті і формування інформаційного суспільства / В. Кремень // Інформатика та інформаційні технології в навчальних закладах. - 2006. - № 6. - С. 5-9. 6. Крушельницька Я. В. Фізіологія і психологія праці: [навч. посіб.] / Я. В. Крушельницька. - К. : КНЕУ, 2000. - 232 с. 7. Тхоржевський Д. О. Методика трудового та професійного навчання. Ч. 2. Загальні засади трудового навчання / Д. О. Тхоржевський. - К. : НПУ ім. М. П. Драгоманова, 2000. - 186 c.

\section{МОРАЛЬНЕ ФОРМУВАННЯ ДІТЕЙ ШКІЛЬНОГО ВІКУ У ВЗАЕМОДІЇ СІМ'Ї І ШКОЛИ}

Короленко В. Л. Моральне формування дітей шкільного віку у взаємодії сім’ї і школи.

У статті розглядається важливість морального формування дітей шкільного віку на основі педагогічних досягнень людства, користуючись у процесі виховання досвідом національної, сімейної педагогіки і педагогіки інших народів. Підкреслюється здатність ефективного використання педагогічних знань різних народів. Наголошується на важливості уміння учителів користуватися особистими моральними знаннями і досвідом у взаємодії з дітьми шкільного віку в загальних навчальних закладах (бесіда, роз'яснення, особистий приклад), підтримання їх в життєвих ситуаціях.

Ключові слова: мораль, поведінка, цінність, виховання, формування. 